\title{
The Use of Information and Communication Technology (ICT) in Teaching ESL Writing Skills
}

\author{
Melor Md Yunus ${ }^{1}$, Norazah Nordin ${ }^{1}$, Hadi Salehi ${ }^{1,2}$, Mohamed Amin Embi ${ }^{1} \&$ Zeinab Salehi ${ }^{2}$ \\ ${ }^{1}$ Faculty of Education, Universiti Kebangsaan Malaysia (UKM), 43600 Bangi, Selangor, Malaysia \\ ${ }^{2}$ Faculty of Literature and Humanities, Najafabad Branch, Islamic Azad University, Najafabad, Isfahan, Iran \\ Correspondence: Hadi Salehi, Faculty of Literature and Humanities, Najafabad Branch, Islamic Azad University, \\ Najafabad, Isfahan, Iran. Tel: 60-176-538-260. E-mail: hadisalehi1358@yahoo.com
}

$\begin{aligned} & \text { Received: April 14, } 2013 \quad \text { Accepted: May 10, } 2013 \quad \text { Online Published: June 3, } 2013 \\ & \text { doi:10.5539/elt.v6n7p1 }\end{aligned}$ URL: http://dx.doi.org/10.5539/elt.v6n7p1

\begin{abstract}
Despite the existence of many studies showing positive effects of using Information and Communication Technology (ICT) in the teaching and learning process in general, the use of ICT in teaching writing skills in English as a Second Language (ESL) classrooms is still not very encouraging. This study attempts to seek findings on the use of ICT in the teaching of ESL writing skills in Malaysian secondary schools. This paper just reports one part of the findings obtained from a big project which was conducted in Malaysian secondary schools in five areas of Malaysia. This study focuses solely on the data collected from four English teachers in a secondary school in Kuala Lumpur who were interviewed by the researcher. This study revealed that the use of ICT in the teaching of ESL writing was very low. Advantages of using ICT were reported to be attracting students' attention, facilitating students' learning process, helping to improve students' vocabulary and promoting meaningful learning. Disadvantages found included the difficult class control, distraction and the students' tendency to use short forms in their writing. It was also revealed that teachers are generally weak in managing problems and planning activities involving the use of ICT in the teaching of ESL writing. The results of this study are hoped to provide insights to the Ministry of Education in Malaysia to improve the low use of ICT in teaching ESL writing skills.
\end{abstract}

Keywords: Information and Communication Technology (ICT), English as a Second Language (ESL), Writing, Teaching, Learning

\section{Introduction}

Since the implementation of the first computer system in the 1960s, different measures and plans have been developed to increase the integration of Information and Communications Technology (ICT) in all educational fields (Nordin, Embi \& Yunus, 2010; Nordin et al, 2010; Salehi \& Salehi, 2012; Ynus, Salehi \& Chenzi, 2012). The notion of ICT in educational fields refers to systems that enable gathering, manipulation, management, access, and communication of information in different forms. The Ministry of Education in Malaysia has developed three major plans for using ICT in education (Ministry of Education Malaysia, 2003). The first plan emphasizes that ICT should be for all students, meaning that ICT is utilized as an enabler to decease the existing digital gap between the schools. The second plan refers to the function of ICT in education as a teaching and learning tool. This plan also emphasizes the use of ICT as an educational tool for obtaining and communication information. The third plan stresses on ICT usage to enhance productivity, effectiveness and efficiency of the management system. In this plan, ICT can be greatly utilized to mechanize and update work processes such as financial management, lesson planning and management of information systems. This study specifically aims to investigate the perceptions of Malaysian secondary school English teachers about the use of ICT in teaching English as a Second Language (ESL) writing skills.

\section{Literature Review}

Writing skill which is an important aspect of language learning refers to the process of encoding the words (Floyd et al., 2007). Although ICT can be regarded as an important tool to enhance the teaching of writing skills (Melor Md Yunus, 2007), there are some disadvantages in terms of using this tool. Moreover, teachers have to take note on the matters in planning the activities involving the use of ICT and managing problems arising from the activities planned. The following sub-sections discuss an example of ICT tools to show the advantages and disadvantages of 
using ICT in teaching writing skills. Moreover, some of the issues involved in managing problems and planning activities using ICT tools have been discussed and reviewed.

\subsection{Advantages and Disadvantages of Using ICT in Teaching ESL Writing Skills}

One of the popular tools commonly adapted in the teaching of writing skills is the use of blogs. According to Kelly \& Safford (2009), blogging provides "a real-world digital medium for communication". It is a multi-dimensional tool that not only offers a container for writing but also has the possibility of multiple audiences and access points" (p. 119). In their research on the effectiveness of using the online writing approach in teaching writing, Kelly \& Safford (2009) conducted a research project in 6 different classes during 2006 Soccer World Cup to analyze how the students employed complicated sentence structures in their writing on a soccer weblog. They explored how the effect of a short-term, popular, worldwide event and an online platform for communication provided an opportunity of writing skill improvement where students started to use complex sentence structures. This research shows positive findings in terms of the students' interest in presenting ideas and responding to their classmates' ideas by commenting on the blog. Similarly, Holder (2006) claimed that online blogs let bloggers get feedback from more than one person, and this kind of peer feedback is more effective than traditional self-correction. Moreover, Lenhart et al. (2008) concluded that blogs are common platforms for teenagers to express their viewpoints, and there is sufficient evidence to support that students having personal blogs tend to be prolific writers in the school. In fact, by using blogs in the teaching of writing, the positive interactivity for the teaching and learning of sentence grammar will be increased.

Research on the use of ICT tools in ESL writing classroom has shown that ICT makes a supportive and encouraging environment for the students to increase their writing skills in terms of quality and quantity (Lam \& Pennington, 1995; Bialo \& Sivin-Kachala, 1996; Goldberg, Russell \& Cook, 2003; Fidaoui, Bahous \& Bacha, 2010). On the other hand, the literature suggests that there are some disadvantages in terms of using ICT in the teaching of writing skills (Salehi \& Salehi, 2011; Yunus \& Salehi, 2012). The use of computer technology could cause the lackadaisical attitude among students whereby they will not take their work seriously. Moreover, ICT tools distract students' attention in the classroom and provide a tendency for the students to use short forms and informal abbreviations in their writing tasks (Yunus et al, 2013). The presence of ICT tools in the classroom makes the students negatively involved during the class time and makes the class control difficult for the teachers (Yunus et al, 2013).

\subsection{Managing Problems and Planning Activities Involving ICT in Teaching ESL Writing Skills}

Lawrence, McNeal \& Yildiz (2009) claim that teachers need to consider several matters in managing problems which could arise from the activities planned. Firstly, teachers need to explain to students how to do tasks on the computer (e.g., cutting and pasting, drawing tables, resizing the fonts, and changing the colors in their manuscripts). Secondly, when it comes to the brainstorming session, the teacher has to lead the process of brainstorming options for presenting the students' work to the audience based on the type of text the students wanted to share. Thirdly, the teacher cannot take for granted little things which the students might not know. The teacher should make an effort to model certain expected behaviors, for instance, how to search the web for specific information, and how to save it in specific drive. The fourth suggestion is to provide students with research strategies to assist them progress in their writing process. Lastly, teachers should constantly ask the students some questions to understand their needs and then guide them while doing their research projects. Proper guidance and scaffolding to guide students along the activities planned using ICT are needed so that all learners are able to follow and benefit from the tasks planned (Lawrence, McNeal \& Yildiz, 2009).

Although blogs can be a useful tool for the instruction of writing skills, some researches highlighted the drawbacks of using blogs (Anderson \& Balajthy, 2009; Yunus, Kiing \& Salehi, 2013). Two of the drawbacks are that students will not take their activity seriously and will not use what they have learned in their blog postings. However, as pointed out by West (2008), as educators move from traditional written responses to literature into online forums, they find that students still use the literary discourse from the classroom, along with asserting their own personalities in their posts. This is because students understand that there is an online social context for their work and they often comply with certain expectations without teacher prompting to impress their peers (West, 2008).

In short, the literature suggests different problem management procedures which depend very much on the problems encountered by the teachers. Some of the problem management skills elaborated above are to organize the curriculum, provide clear explanation to students prior to the tasks given, lead brainstorming sessions, model certain expected behaviours, help students by providing suggestions and research strategies through the writing 
process, give proper scaffolding along the activities planned and to set rules about teacher expectations and the form of acceptable language within online environments.

On the other hand, various activities which involve the use of ICT could be adapted to assist the instruction of writing. These activities or programmes should not be restricted to in-school activities only. Lawrence, McNeal \& Yildiz (2009) claimed that adolescents get involve in different literacy practices outside the school because they interact with different types of non-traditional texts and sources of information, access and mass media and different cultures, and interact with people from diverse backgrounds and perspectives using the computer technologies.

In summary, various kinds of planning and different types of activities involving ICT in the teaching of reading and writing could be planned. The use of new technologies enables learners to communicate with different people using multiple forms of non-traditional texts and sources of information. Teachers' classroom practices have to be re-examined due to the everyday technology effects on the students' literacy practices. Holiday literacy programmes which cover lessons on writing skills involving the use of ICT could be planned to facilitate students' learning process. Teachers can also use the social networking tools such as Facebook and create a group to encourage academic sharing and discussion among the learners.

\section{Methodology}

This paper is just one part of a huge project. The general purpose of the main study was to explore the effectiveness of using ICT in teaching ESL writing skills in Malaysian secondary schools. To achieve the purpose of the study, a total of 33 English teachers were interviewed. The teachers were selected from secondary schools from five different areas of Malaysia, namely Alor Setar, Tawau, Tuanku Jaafar, Johor Bahru, and Kuala Lumpur. This study is a qualitative research in nature because in order to get deeper understanding of the participants' perceptions, a semi-structured interview was used to explore teachers' perceptions and practices of using ICT in teaching writing skills in ESL classrooms. The data obtained from the interviewed teachers who were teaching in Kuala Lumpur area are reported in this paper. All the participants were pragmatically and purposively selected.

The objective of designing interviews in this study was to obtain rich information about the participants' perceptions and attitudes towards the use of ICT in teaching writing skills in English as a Second Language (ESL) classroom. The questions for the interviews were developed based upon the nature of the research questions.

In general, interviews tended to provide in-depth and detailed information about how Malaysian secondary school teachers actually reacted to the use of ICT in teaching ESL writing skills. The interview questions were developed by the researchers and initial modifications were made in order to tailor the questions to reflect the nature of the research questions. In the development process of the interview questions, in order to ensure the content validity, first of all, the present researchers reviewed the relevant literature and examined the interview protocols designed for similar purposes. The first draft of the interview questions were developed considering the issues pointed in the literature. Then, the content validity and face validity of the interview protocol were checked by a panel of experts. The experts' comments and suggestions were implemented to develop the second draft of the protocol. To ensure the reliability of the interview questions, the second drafts were piloted on 3 English teachers. The piloting of the second drafts of the interviews showed that all the questions were clear and the interviewees were not encountered with any problems due to the wording of the questions. The questions of the interview were structured to find the answer for the following research question:

- What are the advantages and disadvantages of using ICT in teaching writing skills in ESL classrooms?

- How do Malaysian secondary school English teachers manage problems and plan activities involving ICT in teaching ESL writing skills?

Before conducting the study, the necessary permissions were obtained from both the school principal and the teachers. Moreover, the consent forms were read and signed by all four participants before conducting the interviews. All the interviews were conducted in English in November 2012. The interviews lasted for about 30 to 45 minutes and they were audio-recorded. After conducting the interviews, the recorded interviews were transcribed verbatim. They were also organized, coded and analyzed. In order to analyze the interview data, several steps have been conducted. Right after each interview session, the researcher transcribed the recorded interviews and referred to his notes on what he has jotted down as the interview went along to avoid losing any important data which might become significant to the findings of this research. The researcher then contacted the research interviewees to confirm the accuracy of the transcriptions and notes as interpreted by the researcher. All participants were given a pseudonym for the purpose of anonymity. 


\section{Results}

\subsection{Participants' Demographic Information}

Table 1 summarizes the details of the interviewed teachers. Four out of six English teachers in the school participated in the interview sessions. The names of the teachers have been changed to ensure a high level of anonymity and to protect their privacy as well. All four teachers were female. The interviewer could not get any male teacher to be interviewed as all the six English teachers in that school are female. This is a very common phenomenon as the teaching profession has always been dominated by the women due to the nature of the job. All the teachers are above the age of 30 meaning that they have at least5 years of teaching experience.

Table 1. Basic Information about Interviewed teachers

\begin{tabular}{lllll}
\hline Area & Pseudonym & Gender & Age & Teaching experience (Year) \\
\hline Kuala Lumpur & Nora & F & 32 & 9 \\
& Rinie & F & 40 & 15 \\
& Asyikin & F & 46 & 21 \\
& Anne & F & 54 & 30 \\
\hline
\end{tabular}

\subsection{Main Findings of the Interviews}

The main findings of the study are presented based upon the following themes:

\subsubsection{Advantages and Disadvantages of Using ICT}

When the teachers were asked to give their responses on the benefits of using ICT in teaching writing skills, most of them stated that ICT tools can be useful and effective in conducting writing activities. They unanimously believed that the conventional methods of teaching ESL writing make the students bored during the class time. Nora stated that:

Using ICT can motivate my students to be creative and learn in an enjoyable environment. For example, they can easily write their essays anytime because they can find a lot of information about each topic on the web.

In agreement with Nora's opinion, Anne referred to the benefits of surfing the net for the students to improve their writing skills. She added that:

Students can use the Internet to search for the information they may need for writing. For example, if they are going to write about a personality they admire, they can 'google' to find more information about the person they selected.

Moreover, Asyikin responded very positively towards the view of ICT being utilised for the purpose of teaching writing skills. She stressed on how ICT as a teaching tool could help make the lesson more interesting, which in turn could keep the students focused in class. When the teachers can draw the students' attention in the class, the lessons could be carried out more smoothly and when that happens, the students will not be so bored as well. In agreement with Asyikin's opinion, Nora highlighted how the current generation of students are put side by side with ICT. Students, as she has said, are using the ICT tools themselves even out of school. The current twenty-first century students as Sweeny (2010) put, should be treated differently in terms of teachers' methods of teaching. It is suggested that if students are able to use the ICT tools themselves outside the school, it would really benefit them if the ICT tools are integrated in the teaching of writing as well.

Rinie commented on how the current generation of students are different in terms of their creativity and self-discovery skills. She believed that today's students are able to do many things on their own including searching for educational related materials online. She also added the following with an example:

We teachers are not bound to the traditional way of teaching. The students now are different. Students are more creative now; they are able to search for materials on the net themselves. Once I gave my Form 4 students a writing exercise. It was a formal letter. I did not explain to them the format or the content they should include in the letter. I just gave them the topic. After the school holiday, I expected to repeat the lesson but the students had already completed the exercise! I asked them how they did it and they said they just searched the topic in the 'Google'.

When the teachers were asked about the disadvantages of using ICT in teaching writing skills, most of the teachers 
referred to the students' use of abbreviations in writing tasks, insufficient time and plagiarizing materials on the net. Nora highlighted the negative effects of using short forms by the students. She believed that the informal abbreviations ruin the students' writing tasks. She added that:

Speaking from my own experience, I feel that when the students use too much ICT tools, they tend to use a lot of short forms like 'cos' to mean 'because', 'ur' to mean 'your' and many others. They also like to use this SMS language in their essay writing. That's horrible, isn't it?

Moreover, Rinie emphasized that why there is a need to use ICT when non-ICT-based lessons could do the same for her and her students. She also referred to the insufficient time for instruction when ICT is used. She explained that:

I think a lot of time will be wasted when we use ICT. If you only have one period of English, you have only 40 minutes. When you use the computer lab, students need some time to get there. If you're lucky, the LCD is alright and it can detect your laptop. If you're not, you'll spend time with the technical problems. Even if you have double periods, you still do not have enough time to finish what you plan to do with the students. So sometimes I think why do we want to use ICT when we can always do it face-to-face with the students?

Similarly, Asyikin pointed out that:

You can't be able to give so much input when you want to use ICT. Suppose you assign homework for your students to do. You give the students writing exercises in a blog or ask them to write a post on the blog. You cannot expect to get all 100\% students completing the work via the blog. There will be plenty of excuses given by them when they can't complete the task. No internet access will be the main excuse given. While if you give them a task in hard copies like handouts, there is no excuse for them to escape from doing the task.

In the same way, Anne was worried about what the students could actually gain from the writing lessons with the use of ICT. She gave an example of how the students might not be able to relate what they had learnt via ICT to the tasks they attempted. She also inserted her view on the importance of teachers' capabilities in using ICT to ensure that students could follow the lesson well. She specifically stated that:

When you want to use ICT, you need to be good at it. You need to be competent. If not, your lesson will not run smoothly. If teachers can't use ICT competently, it's better for them not to use it. Otherwise, students might not get what you're trying to teach. That's very dangerous. Let's say you use songs to teach them vocabulary before attempting the writing part. After singing and enjoying the song, they might forget the words and just remember the tune of the song.

4.2.2 Managing Problems and Planning Activities Involving ICT

Classroom management usually includes teachers' actions to engage students in the learning process. Specifically, it encompasses actions such as establishing and maintaining ICT equipment, handling of misbehaviors, providing instruction, attending to students' cognitive and emotional needs and managing group activities (Emmer \& Stough, 2001). Therefore, it more focuses on a positive environment which is conducive to make students involve and they are more satisfied in the learning process. In order to overcome the problems that occur regarding ICT usage in ESL classroom, Anne stated that:

Teacher could be more creative in thinking and be more active in classroom by giving students lessons which are in agreement with the students' interest or students' level. Therefore, problems regarding the management of students and ICT in ESL classrooms can be overcome easily.

The problem management adapted by the interviewees from the challenges faced were probed. For example, Anne stated that "If there are problems, I will change my lessons. I will photocopy exercises from the reference books and teach using those materials". Moreover, Rinie highlighted the way of assigning take-home tasks to students when there were problems for internet access in school. She added that:

With the problem on slow connection, I will assign students to find reading materials at home and print them out. No matter what, there shouldn't be any spoon feeding. Those materials they find and print out will be useful in their writing process.

Asyikin also had something to say about this matter:

If I really want to use ICT, I will consult the technicians or other teachers who are more expert in ICT to help me. If not, I will just use my own methods of teaching reading and writing without using ICT.

Asyikin implied that if there is a will, there is always a way. For her, if she really wanted to use ICT, she would consult the school technicians or her colleagues who were more competent in using ICT. When that did not help, 
she would just revert to non-ICT teaching methods. As for Nora, when she had problems with the ICT tools, she would request for assistance either from the school technicians or the students. She said "I will get the school technicians to help me with the computers. But sometimes they are busy and I will get students to help".

One the other hand, interviewees were asked to share their plans for writing activities involving the use of ICT in teaching. However, not every interviewee had used ICT in the teaching of writing. There are so many activities that can be carried out by using ICT in order to teach writing. In writing activity, using the Word-processors has made a huge difference for many students in learning writing in English language. Students can write pieces of written work for many times over and over again in order to get a neat piece of writing by using ICT tools and present it to the teacher in a neat form of work. To support this idea, Asyikin stated that:

Apart from the web-based activities, as a teacher, I use the computers' word processing software for other stages of the class. For example, I use this software during the brainstorming activity. This again is a personal wish to try out teaching a common classroom activity using ICT. I wish to see how the students react to the activity. This again is an attempt to integrate ICT into the class by looking at as many ideas through the web based activities.

Teaching language learners by using ICT has distinct advantages that are related not only to language education but prepares students for today's information society. Computer technologies and the Internet are powerful tools for assisting language teaching because Web technology is a part of today's social needs, meaning that language learners now can learn through writing e-mail and conducting online research (Wang, 2005). ESL teachers can collect teaching of writing materials by looking at the web based on English language sites. This has been agreed by Anne who pointed out that:

Teachers can just go to TESL website or any other related web site and just select the suitable materials or activities that can enhance the students' interest in writing. This can be as a reference or just to show evidence for students in gaining more information for future lessons.

Nora referred to her experience regarding the use of ICT in teaching ESL writing. She used ICT in the pre-writing stage and added that:

I use ICT to search for information regarding the topic of writing that I'm going to teach. Let's say I'm about to teach factual writing about pollution. I will search for the information about pollution, the types and details of pollution. Then I print and photocopy the related texts for my students to refer.

Similarly, Rinie stated that:

My activities will focus more on the pre-writing parts. I will use cartoon strips I get from the net, show the strips to them to attract their attention. Actually, we don't focus much on how to conduct interesting activities for writing activities. We just don't have time for that. We focus more on how to score in the exams. I know having different activities would benefit them but right now, exam is more important. We need to give more drilling practice to them so that they can do well.

It should be remembered that teachers must make sure that the websites chosen for learners to browse and search for information are tested to ensure that the language is simple enough for them to understand without having to resort to translating the texts word by word. At first, the teachers can introduce the websites which present simple basic information such as meaning or pronunciation of the words that are good for the beginners. However, Rinie believed that the teachers should not be worried about the technology and the way it should be used. She stated that they learn everything because they have been brought up with this technology. She added that:

I do not feel worried about the learners having "techno-fear" since they are young adult learners who have been brought up with IT at home. Therefore, the lesson will be fairly ambitious in allowing learners to freely search on-line. This I hope will lead to greater learner autonomy, as they will be deciding in groups what to look for and to what depth. After the class, I hope to be able to reflect and see how successful I was in caring out the activity by using ICT in my ESL classroom, and what I need to do is to reflect and think a way to improve the integration of ICT into my next classes.

\section{Discussion and Conclusion}

In general, there are many advantages and disadvantages regarding the use of ICT in the teaching of ESL writing in schools. For the advantages, it is reported that using ICT could help to meet the teachers' teaching objectives as ICT aids the teaching process. This comment resonates with Melor Md Yunus (2007) finding that ICT could be a learning tool in education. Moreover, another finding was that ICT is viewed not as a conventional method, but a 
new creative method of teaching which the researcher interpreted, as one which could activate active learning among the students (Mullamaa, 2010).

The integration of ICT in the teaching of writing was said to encourage learners' independence and self-discovery skills like searching for educational related materials online. This data supports findings by Blachowicz et al. (2009) who found out that the learning technology allowed students to develop independent work habits and to build both their skills and confidence about literacy and about using technology. Students could take responsibility for finding answers to suit their own learning needs (Choi \& Ho, 2002 as cited in Sweeny, 2010).

For the disadvantages, there were only three main findings gained which are the problems on class control, distraction and the improper use of short forms as in the short messaging system (SMS). The three main disadvantages could be overcome without much problem. With stricter ground rules before bringing students to the computer laboratories, teachers would not face so many problems with class control. Moreover, with a central control of the computers, students might not get to visit other irrelevant websites that could distract them from completing the tasks given. As for the tendency to use short forms in writing, students could be given advice and constant reminder so that they will not repeat the mistakes in their writing. As mentioned by Lee (2007), it is important to set some basic rules about the teacher's expectations and the form of language that is appropriate in online environments. This is also to avoid the use of harsh or improper language within the online community.

Teachers seemed to be weak in managing the problems occurred while they were using ICT in teaching of writing skills. Feedback given was that if they had problems with the ICT equipments, they would revert to consulting the school technicians or other colleagues who are more competent in using ICT. Assistance either from the students was also one of the options used. Teachers' creativity level seemed to be quite low as the activities planned only involve those of lower levels like using the exercises from the English textbook. In fact, ICT is mostly used to search for writing materials before teaching the lesson.

\section{References}

Anderson, R., \& Balajthy, E. (2009). Stories about struggling readers and technology. The Reading Teacher, 62(6), 540-542.

Bialo, E. R., \& Sivin-Kachala, J. (1996). The effectiveness of technology in schools: A summary of recent research. School Library Media Quarterly, 25(1), 51-57.

Blachowicz, C., Bates, A., Berne, J., Bridgman, T., Chaney, J., \& Perney, J. (2009). Technology and at-risk young readers and their classrooms. Reading Psychology, 30(5), 387-411. http://dx.doi.org/10.1080/02702710902733576

Choi, C. C., \& Ho, H. (2002). Exploring new literacies in online peer-learning environments. Reading Online, 6(1). Retrieved September 10, 2012, from readingonline.org/newliteracies/lit_index.asp?HREF=choi/index.html

Emmer, E. T., \& Stough, L. M. (2001). Classroom management: A critical part of educational psychology with implications for teacher education. Educational Psychologist, 36(2), 103-112.

Fidaoui, D., Bahous, R., \& Bacha, N. N. (2010). CALL in Lebanese elementary ESL writing classrooms. Computer Assisted Language Learning, 23(2), 151-168.

Floyd, R. G., Keith, T. Z., Taub, G. E., \& McGrew, K. S. (2007). Cattell-Horn-Carroll cognitive abilities and their effects on reading decoding skills: $\mathrm{g}$ has indirect effects, more specific abilities have direct effects. School Psychology Quarterly, 22(2), 200-233.

Goldberg, A., Russell, M., \& Cook, A. (2003). The effect of computers on student writing: A metaanalysis of studies from 1992 to 2002. Journal of Technology, Learning, and Assessment, 2(1). Retrieved from http://www.jtla.org

Holder, C. R. (2006). New media and new literacies: Perspectives on change. EDUCAUSE Review, 41(6), 76-77.

Kelly, A., \& Safford, K. (2009). Does teaching complex sentences have to be complicated? Lessons from children's online writing. Literacy, 43(3), 118-122. http://dx.doi.org/10.1111/j.1741-4369.2009.00501.x

Lam, F. S., \& Pennington, M. C. (1995). The computer vs. the pen: A comparative study of word processing in a Hong Kong secondary classroom. Computer-Assisted Language Learning, 8, 75-92.

Lawrence, S. A., McNeal, K., \& Yildiz, M. N. (2009). Summer program helps adolescents merge technology, popular culture, reading, and writing for academic purposes. Journal of Adolescent and Adult Literacy, 52(6), 
483-494.

Lee, C. K. (2007). Affordances and text-making practices in online instant messaging. Written Communication, 24(3), 223-249.

Lenhart, A., Arafeh, S., Smith, A., \& Macgill, A. R. (2008). Writing, Technology and Teens. Washington, DC: The Pew Internet \& American Life Project.

Melor Md Yunus. (2007). Malaysian ESL teachers' use of ICT in their classrooms: Expectations and realities. European Association for Computer Assisted Language Learning. ReCALL, 19(1), 79-95.

Ministry of Education Malaysia. (2003). Education Development Plan: 2001-2010.

Mullamaa, K. (2010). ICT in language learning - benefits and methodological implications. International Education Studies, 3(1), 38-44.

Nordin, N., Embi, M. A., \& Yunus, M. M. (2010). Mobile learning framework for lifelong learning. Procedia Social and Behavioral Sciences, 7, 130-138.

Nordin, N., Hamzah, M. I., Yunus, M. M., \& Embi, M. A. (2010). The mobile learning environment for the in-service school administrators. Procedia - Social and Behavioral Sciences, 7, 671-679.

Salehi, H., \& Salehi, Z. (2011). Washback effect of high-stakes tests on ICT usage: Teachers' perceptions. Australian Journal of Basic and Applied Sciences, 5(12), 1976-1984.

Salehi, H., \& Salehi, Z. (2012). Integration of ICT in language teaching: Challenges and barriers. Proceedings of the 3rd International Conference on e-Education, e-Business, e-Management and e-Learning (IC4E, 2012), IPEDR Vol. 27, 215-219.

Sweeny, S. M. (2010). Writing for the instant messaging and text messaging generation: Using new literacies to support writing instruction. Journal of Adolescent and Adult Literacy, 54(2), 121-130. http://dx.doi.org/10.1598/JAAL.54.2.4

Wang, L. (2005). The advantages of using technology in second language education. Technology Horizons in Education Journal, 38-41.

West, K. (2008). Weblogs and literary response: Socially situated identities and hybrid social language in English class blogs. Journal of Adolescent \& Adult Literacy, 51(7), 588-598.

Yunus, M. M., Kiing, J. L., \& Salehi, H. (2013). Using blogs to promote writing skill in ESL classroom. Proceedings of the 4th International Conference on Education and Educational Technologies (EET '13), 109-113.

Yunus, M. M., Nordin, N., Salehi, H., Redzuan, N. R., \& Embi, M. A. (2013). A review of advantages and disadvantages of using ICT tools in teaching ESL reading and writing. Australian Journal of Basic and Applied Sciences, 7(4).

Yunus, M. M., \& Salehi, H. (2012). The effectiveness of Facebook groups on Teaching and Improving Writing: Students' perceptions. Journal of Education and Information Technologies, 1(6), 87-96.

Yunus, M. M., Salehi, H., \& Chenzi, C. (2012). Integrating social networking tools into ESL writing classroom: Strengths and weaknesses. English Language Teaching, 5(8), 42-48. http://dx.doi.org/10.5539/elt.v5n8p42

\section{Copyrights}

Copyright for this article is retained by the author(s), with first publication rights granted to the journal.

This is an open-access article distributed under the terms and conditions of the Creative Commons Attribution license (http://creativecommons.org/licenses/by/3.0/). 